\title{
TACTICAL AND CRIMINALISTIC ASPECTS OF POLICE NEGOTIATIONS IN CRISIS SITUATIONS
}

\begin{abstract}
Teams of police negotiators, who are summoned when there is a crisis situation, are very important in the police tactics. Their task is to establish verbal communication with the perpetrator of a crisis situation and to bring about a peaceful solution to the problem. It can therefore be assumed that the aim of the negotiations is to make the perpetrators or the perpetrator surrender, and in a situation where there is a real threat to the lives of people participating in a crisis situation to "buy time" to prepare the best opportunity for another tactical solution (e.g.: an assault). Police negotiations are treated as an alternative to enforcement solutions of crisis situations, such as the police forces' storm without reconnaissance, police forces' storm after reconnaissance or using snipers. The first full-time negotiation section in Poland was established in 1992. Two years later, it was assumed that sections of police negotiators would be created in each province. Currently, full-time negotiators serve in the Negotiation Section of the Operational Support Department of the Anti-Terrorist Operations Bureau of the General Police Headquarters of Poland, while non-permanent negotiation teams operate in each provincial headquarters and in the Warsaw Metropolitan Police Headquarters.
\end{abstract}

Keywords: Police negotiations, crisis situation, tactics, suicide, hostage, dangerous tool, explosives.

\section{INTRODUCTION}

For more than 40 years, police negotiations have been a preferred tactic used as alternative measures to enforcement solutions, and they serve to resolve crisis situations related to hostage taking, terrorist attacks, suicide attempts and any other situations which result in a breach of security and public order.

Irrespective of the fact whether the situation is linked to a security threat of one person or a group of persons, it implies the necessity of a number of actions to eliminate the threat and the restoration of the state prior to its occurrence. One of the methods designed to eliminate or reduce the danger occurring as a result of a crisis situation is conducting negotiations with the perpetrator or perpetrators. It should be noted that crises are an integral part of the life of the society and individuals. It is not always possible to prevent such situations, but with the skills of specially trained police negotiators, in case of the mentioned crisis situations their effects can be reduced, and the course of the crisis can be influenced.

\footnotetext{
${ }^{1}$ Dorota Semków, PhD, Faculty of Law and Administration, University of Rzeszów, e-mail: dsemkow@ur.edu.pl.

Dr Dorota Semków, Wydział Prawa i Administracji, Uniwersytet Rzeszowski, e-mail: dsemkow@ur.edu.pl.
} 
The subject of negotiations is a determinant of defining them. In the professional literature, police negotiations are the negotiations linked to the resolution of situations connected with a threat to public security and order ${ }^{2}$. It is worthwhile to note that the term police negotiations can be understood in a narrow and wide sense. This above-mentioned definition presents the broad sense of the term. In this sense, police negotiations also include preliminary negotiations, understood as both talks until a police negotiator has arrived at the place of the incident, as well as any other negotiating talks conducted during the incidents by policemen, the objective of which is to resolve conflicts. Therefore, this term includes also mediation conducted by a police officer or other forms of "third-party" intervention. Police negotiations in the strict sense are actions following the procedures described in ministerial legal acts ${ }^{3}$. Specifying the general nature of police negotiations, it should be considered that they constitute a communication process between a perpetrator (perpetrators) of the incident, an offence, and an authorized police officer, whose purpose is to work out a solution which is relevant from the viewpoint of public security. As stressed by D. Loranty, in contrast to the classic negotiations, the primary objective of police negotiations is not reaching an agreement, although it should not be excluded, but obtaining the best possible resolution of the incident. It may therefore be considered that the most important objective is the offender's withdrawal from further criminal activities, a possible development of another solution; arresting while committing an act or collection of the offence evidence to prove the guilt ${ }^{4}$. This issue is closely connected with the tactical and criminalistic aspect of the police officers' operations. It is to be noted that the criminalistic tactics is a field including a science of targeted and effective methods of achieving objectives defined by the functions of criminalistics in a quick, ethical and legitimate manner. They are the following features of criminalistics: reconnaissance, detection, evidence collection and prevention ${ }^{5}$. In the context of police negotiations conducted in crisis situations, special attention should be paid to implementation of the preventive function, sometimes referred to as the prophylactic function. It runs in three directions. The first one is linked to a threatening factor, the second one with a threatened factor, and the last one with the circumstances shaping the threat ${ }^{6}$.

Returning to the subject matter of the definitions describing police negotiations in the professional literature, it is worth pointing to the definition which describes the goal of police negotiations as working with a person in a crisis towards a peaceful solution that previously seemed impossible or, in other words, reconciling the problems of the perpetrator of the crisis situation with a need to maintain peace for the whole society ${ }^{7}$. Successful negotiations have been unconditionally defined in the professional literature as a crisis incident that did not cause any injury to anyone involved - including the perpetrator of the

\footnotetext{
${ }^{2}$ K. Jałoszyński, Niestandardowe negocjacje policyjne [in:] Komunikacja w sytuacjach kryzysowych III, ed. J. Stawnicka, Katowice 2012, p. 51.

${ }^{3}$ D. Biel, Badania sytuacji kryzysowych/policyjnych. Wstęp do dyskusji [in:] Komunikacja w sytuacjach kryzysowych II, ed. J. Stawnicka, D. Biel, Katowice 2011, p. 19.

${ }^{4}$ D. Loranty, Zasady prowadzenia...., p. 251-252.

5 T. Hanausek, Kryminalistyka. Zarys wyktadu, Kraków, 2005, p. 38-42.

${ }^{6}$ Ibid, p. 72-73.

${ }^{7}$ P. Staff, Police Negotiation Techniques from the NYPD Crisis Negotiations Team, 20.02.2018, www.pon.harvard.edu (access: 21 March 2018).
} 
incident, hostages (if a crisis situation involves taking and detaining hostages) and police officers ${ }^{8}$. Such an objective can be obtained using several methods ${ }^{9}$.

In view of the above, it can be concluded that police negotiations are an extremely important tactical tool for crisis management, which has been identified with the work of police negotiators for many years ${ }^{10}$. Undoubtedly, the development of negotiating skills was affected by defeats of security organs in the fight against criminals and terrorists initiated in the $1970 \mathrm{~s}^{11}$ resulting from unprecedented mass-scale terrorist attacks, and thus taking hostages and carrying out abductions ${ }^{12}$. As a result of these events, European police forces started organising a new specialty, i.e. police negotiations. As in the United States, a study has been launched on cases of criminal offences in the course of which the perpetrator was communicated with. A conclusion was reached that there are some fixed mechanisms in the perpetrators' behaviour, concerning in particular the area of psychology, psychiatry and sociology. Thus, in the context of analyses of perpetrators' profiles made by police negotiators, there is an increasing emphasis on the need for cooperation between police officers and psychologists and psychiatrists ${ }^{13}$.

The research results enabled to work out appropriate procedures for negotiators for dealing with perpetrators. Considering the complexity and diversity of crisis situations, it is impractical to believe that negotiators can learn concrete strategies for each situation. It should, however, be stressed that the preferred model of negotiations must be flexible enough to be applied to virtually any situation, regardless of the context, the state of mind or other restrictions. Police organizations in both North America and Europe spend a lot of time and resources to ensure that officers are specially trained in negotiation techniques ${ }^{14}$. One must indicate a diversity of strategies and models of police negotiations. The choice of one of them is determined by many factors that arise during the occurrence of a specific crisis situation, including the profile of a crisis situation perpetrator ${ }^{15}$.

${ }^{8}$ A. Rubio, Perceived outcomes of Swat Negotiations with a Police Psychologist on the Crisis Negotiations Team, Dissertation Submitted to the Faculty of the California School of Forensic Studies, Los Angeles 2015, p. 7-8.

9 M.J. Macmains, W.C. Mullins, Crisis Negotiations. Managing Critical Incidents and Hostage Situations in Law Enforcement and Corrections, London and New York 2015, p. 15.

${ }^{10}$ See more: E. Bowen, S.J. Brown, A.R. Grubb, P. Hall, From "Sad People on Bridges" To "Kidnap and Extortion": Understanding the Nature and Situational Characteristics of Hostage and Crisis Negotiator Deployments, "Negotiation and Conflict Management Research” May 2018.

11 D. Loranty, Zasady prowadzenia negocjacji ze sprawcami zamachów terrorystycznych [in:] Wspótczesne zagrożenia terroryzmem oraz metody dziatań antyterrorystycznych, ed. J. Szafrański, Szczytno 2007, p. 250.

12 See more: M.J. Macmains, W.C. Mullins, Crisis Negotiations..., p. 4-14.

${ }^{13}$ See more: K. Pearce, Police negotiations. A new role for the community psychiatrist, "Canadian Psychiatric Association Journal”, 1977 Jun;22(4), p. 171-175.

14 B. Kelln, C.M. McMurtry, STEPS - Structured Tactical Engagement Process A Model for Crisis Negotiation, "Journal of Police Crisis Negotiations", Volume 7 2007, 29-51.

15 A.R. Grubb, An Exploratory Mixed-Methodological Analysis of Police Hostage and Crisis Negotiation in the United Kingdom, Coventry 2016, p. 30-40. 


\section{LEGAL GROUNDS, TACTICAL ASPECTS OF THE ORGANIZATION OF POLICE NEGOTIATIONS IN POLAND AND THE CLASSIFICATION OF CRISIS SITUATIONS}

The history of police negotiators in Poland dates back to the turn of the 1980s and the 1990s. In the perspective of major changes in the political system, as well as in the face of the emergence of new categories of crimes, in order to meet the needs of the service, the Police leadership took actions which resulted in the creation in the Police of a police negotiator function. Guided by the principle according to which it is the best way to learn from the best and at the same time the best experienced, a group of Polish police officers left for the United States of America in order to acquire the necessary skills from qualified professional negotiators ${ }^{16}$. The first negotiation section in Poland was created on 1 September 1992 in the Anti-Terrorist Department of the Warsaw Metropolitan Police Headquarters. Three years later Polish police officers were sent again to the negotiation training to the USA. Along with their return to the country, the creation of a training system for police negotiators was initiated. It started in 1996. As a result, during the next two years 110 negotiators were trained, but due to the absence of legislation governing their work, in 2000 as few as 10 police negotiators were left ${ }^{17}$. This was the direct cause of the re-launch of training and work on a legal act that would regulate the issue of negotiation activities. The undertaken work resulted in the "Ordinance No. 4 of the Police Commander-in-Chief of 26 March 2002 on the forms and methods of police negotiations"18. It defines the scope and manner of conducting police negotiations, indicates the competent bodies to fulfil these tasks, and situations in which this type of negotiations may be carried out. In accordance with said Ordinance, police negotiations rely on the communication between a perpetrator of a crisis situation and a police negotiator in order to resolve the crisis situation.

Currently, there is a police negotiation system consisting of the Central Unit, which is the Negotiation Team of the Anti-Terrorist Operations Bureau of the General Police Headquarters of Poland and non-permanent teams functioning at the level of each provincial police headquarters ${ }^{19}$.

In the context of the discussed subject, it is worth emphasizing that the Anti-Terrorist Operations Bureau as the organisational unit of the General Police Headquarters of Poland has a dual function in this structure. The priority area of this structure activity is to prepare and maintain readiness to carry out counter-terrorist tasks at the tactical or executive level, as well as performing tasks consisting in conducting combat operations for other police and non-police entities. In order to implement this group of tasks, there is a round-the-clock duty of a combat team in the Anti-Terrorist Operations Bureau (Biuro Operacji Antyterrorystycznych - BOA). The second area of operations covers participation in all actions at the level of organization, legislation, logistics and international cooperation in the area of

\footnotetext{
${ }^{16}$ J. Żółtowski, Funkcjonowanie systemu negocjacji policyjnych w Polsce [in:] Stużby i formacje mundurowe w systemie bezpieczeństwa wewnętrznego Rzeczypospolitej Polskiej, ed. E. Ura, S. Pieprzny, Rzeszów 2010, p. 378.

17 A. Wieczorek, Negocjator w cieniu akcji,www.police.pl (access: 18 March 2018).

18 Official Journal of the General Police Headquarters of Poland 2002 Issue 5, item 25.

${ }^{19}$ D. Piotrowicz, Negocjacje kryzysowe w policyjnym systemie interwencyjnym. Bezpieczeństwo Mistrzostw Europy w piłce nożnej Euro 2012, ed. K. Liedel, P. Piasecka, Warszawa 2011, p. 100.
} 
responsibility ${ }^{20}$. The specific tasks of the BOA were included in $\S 21$ of the "Ordinance No. 8 of the Police Commander-in-Chief of 15 March 2013". The list of tasks also identifies the tasks which relate to conducting police negotiations and to coordinating the preparations of the police to carry out combat operations, mine-laying and pyrotechnic operations, and police negotiations. It can therefore be concluded that police negotiations are an important area of activity of the Anti-Terrorist Operations Bureau officers.

According to the data from July 2017, there were 372 negotiators in the Police at that time, of whom only seven were full-time negotiators in the Negotiation Section of the Operational Support Department of the Anti-Terrorist Operations Bureau of the General Police Headquarters of Poland. Their responsibilities in particular are to protect the implementation of combat operations of the Anti-Terrorist Operations Bureau in terms of negotiations. In addition to conducting negotiations in the situations specified in said regulations, negotiators organise and conduct training sessions for candidates for negotiators and for other bureaux of the Police Headquarters, schools and training centres and external institutions. The police officers of the Anti-Terrorist Operations Bureau also run training workshops for negotiators of individual provinces and the Warsaw Metropolitan Police Headquarters ${ }^{21}$. The prominent role of the officers from the Anti-Terrorist Operations Bureau, and at the same time of police negotiators' work is reflected by the fact that for years this unit has been working in the Atlas task force, comprising central anti-terrorist police units of the European Union countries ${ }^{22}$. The purpose of the Atlas project is to develop a uniform tactical and procedural system, applicable in the event of various terrorist threats within the European Union. Poland is one of the three Member-States of the European Union responsible for the development of standard negotiation solutions ${ }^{23}$. To this end, the Negotiations Section of the Anti-Terrorist Operations Bureau within the intervention units belonging to Atlas takes part in the activities of the working group Atlas Negotiation Forum ${ }^{24}$. The group meetings involve conferences, trainings, exercises, forums and seminars the objective of which is to work out a uniform tactical and procedural system. Poland was an organiser of the many of the above projects. During the meetings of the European Union police negotiators, topics relating to the national systems of negotiations are discussed as well as specific cases are analysed. In view of the increasing level of danger and increasingly diversified factors leading to crisis situations, a system of police negotiators' training is an often-discussed topic.

The Negotiations Section of the Anti-Terrorist Operations Bureau also participates in the activities involving the preparation of negotiators to save human lives. Their work is preceded by the participation in many trainings at both national and international level. This was the area of the training given to the Polish negotiators by the FBI negotiators. They also provide training for police negotiators in Poland as well as to other services ${ }^{25}$.

\footnotetext{
${ }^{20}$ M. Stępiński, Działalność Biura Operacji Antyterrorystycznych Komendy Gtównej Policji w 2013 r., „Kwartalnik Policyjny”, Issue 1/2014, p. 62.

${ }^{21}$ Po pierwsze czlowiek, „Policja 997”, Issue 148/07.2017.

${ }^{22}$ Ibid.

${ }^{23}$ Negocjatorzy policyjni, antyterroryzm.gov.pl (20 March 2018).

${ }^{24}$ M. Stępiński, Negocjacje policyjne. Narzędzie alternatywnego rozwiązania sytuacji kryzysowej, "Kwartalnik Policyjny", Issue 1/2014, p. 72.

${ }^{25}$ Negocjatorzy policyjni, antyterroryzm.gov.pl (access: 18 March 2018).
} 
Provincial negotiators' teams, as well as the negotiators' teams of the Anti-Terrorist Operations Bureau implement the entrusted tasks in accordance with the provisions of said "Ordinance No. 4 of the Police Commander-in-Chief of 26 March 2002 on the forms and methods for police negotiations" 26 .

According to the ordinance, police negotiators participate in particular in three types of crisis situations: taking and detaining hostages; an announcement to commit a suicide; the perpetrator's threat to use dangerous weapons or tools or materials towards persons and property. But it is worth to emphasize that the list of crisis situations, in which police negotiation teams may participate to resolve them is much longer, and it will be discussed later in the article.

In order to present fairly the work nature and manner of police negotiators, it should be noted that the work of these people looks much different than presented in action movie scenes. Having regard to the characteristics of their operations, in accordance with the Ordinance of the Police Commander-in-Chief, negotiations are only conducted in a group ${ }^{27}$. Negotiations are therefore conducted in a team that, in accordance with said legal act, carries out its tasks in the following composition: the commander - team coordinator, the negotiator 1 , the negotiator 2 , the negotiator 3 , the negotiator 4 , the consultant ${ }^{28}$. Consultants are persons whose knowledge and skills are necessary for the proper conduct of the negotiations. Analysing some selected cases of negotiations conducted by negotiation teams, it can be noted that a function of a consultant was usually performed by a miner-pyrotechnician, a psychiatrist, a psychologist, a pedagogue or a fireman. With a view to the most favourable solution of a crisis situation, it should be noted that in fact the police use the full spectrum of persons whose knowledge may contribute to a successful outcome of the negotiations. Considering the diversity of crisis situations, and the increasingly intensive process of internationalization of criminal activity, one should also take into account the fact that foreign language interpreters often have to participate in the negotiation process as well. Due to the fact that in a certain number of incidents, a perpetrator of a crisis situation is a deaf-mute person, the conducted negotiations require, in addition to the standard composition of a negotiation team, the presence of a sign language interpreter.

The need to use the negotiation team is decided upon by the commander of the police action or operation. In accordance with section 5 of the "Ordinance No. 4 of the Police Commander-in-Chief of 26 March 2002 on the forms and methods of police negotiations", the responsibilities of the commander - coordinator of the team are: allocation of tasks and supervision of their implementation; cooperation with the commander of the police action or operation; informing the commander of the police action or operation on the negotiation process and obtaining the approval of these persons for the important arrangements between the negotiator and the perpetrator; informing negotiators on the decisions to be taken by the commander of the police action or operation that are necessary to negotiate; obtaining necessary information to conduct negotiations; drawing up reports on the progress of the

${ }^{26}$ Official Journal of General Police Headquarters of Poland 2002 Issue 5, item 25.

${ }^{27}$ It should be pointed out here that the principle of the team conduct of negotiations in crisis situations applies to all police forces in the world.

${ }^{28}$ If it is not possible to form the team described, in accordance with the Ordinance, negotiations are conducted by a team composed of at least three negotiators: the commander - team coordinator, the negotiator 1 and the negotiator 2 , who takes over the tasks of other negotiators as far as possible. 
negotiations which, together with the negotiation card, are sent to the negotiation organizational unit of the Provincial Police Headquarters immediately after their completion.

The discussed Ordinance in its content clarifies overtly the division of the negotiators' responsibilities during the negotiations. This process is as follows: the tasks of the negotiator No. 1 include establishing a contact and conducting the negotiations with the perpetrator of a crisis situation; as part of the duties assigned to the negotiator No. 2, he/she assists the negotiator No. 1 and, if necessary, he/she replaces him/her; the negotiator No. 3, in addition to providing assistance in conducting the negotiations, documents the course of the negotiations during the negotiations and provides information between the commander of the negotiating team and the negotiators; the negotiator No. 4 is responsible for preparing detailed situational charts and provides assistance in conducting the negotiations. The number of negotiation teams depends on the duration of the negotiations. The negotiations of this type are conducted using in particular two methods. The first of these is a conversation using technical measures and the second type is a direct conversation while ensuring the necessary security.

Considering the highly specific nature of a negotiator's work, an important factor is the selection of a candidate for this role. $\S 3$ of the Ordinance makes clear that only a police officer who has completed training on negotiations organised by the General Police $\mathrm{He}$ adquarters of Poland can be a negotiator. In each province, the Police Commander-in-Chief keeps a list of negotiators serving in the area of the territorial scope of activity in the negotiation organisational units and other negotiating units. The professional literature has emphasised for years the need for police negotiators to have specific character traits and appropriate predispositions that foreordain a given person to perform the function of a police negotiator ${ }^{29}$.

Candidates for police negotiators are recruited among police officers who have been at least several years in the service. A three-stage system of candidate selection includes: an initial assessment carried out each time by a provincial coordinator for police negotiations on the basis of an interview with a candidate; a psychological examination and an interview with a police psychologist; practical training on negotiations at the Police Training Centre in Legionowo ${ }^{30}$. During the recruitment process, when making an initial assessment of a candidate for a position of a negotiator, one should consider the fact that while performing his/her work he/she will have to face various situations threatening public security, which will determine the diversity of obligations imposed on the negotiator. Such a person should show the ability to work in a group and adapt measures to various, even the most complicated crisis situations ${ }^{31}$.

Police negotiators carry out their duties also on the basis of "Ordinance No. 1429 of the Police Commander-in-Chief of 31 December 2004 on the implementation of response

\footnotetext{
${ }^{29}$ A. Grubb, S. Brown, P. Hall, Personality traits and coping styles in UK police officers. Do negotiators differ from their non-negotiator colleagues?, "Psychology, Crime and Law", Volume 21(4) 2015, p. 347-374; A. Slatkin, Crisis Negotiation..., p. 25-38.

${ }^{30}$ J. Żółtowski, Funkcjonowanie systemu..., p. 382.

31 J.L. Greenstone, The Elements of Police Hostage and Crisis Negotiations: Critical Incidents and How to Respond to Them, London and New York 2008, p. 44.
} 
procedures in crisis situations in the police" ${ }^{32}$. It provides a list of crisis situations with a guidance for procedures on the police responses depending on a situation ${ }^{33}$.

Organizational forms of police operations used during the implementation of the tasks related to crisis situations are also defined by "Ordinance No. 213 of the Police Commander-in-Chief of 28 February 2007 on the methods and forms of preparation and implementation of the police tasks in cases of threats to life and health of people or their property or public security and order" ${ }^{\prime 34}$. $\$ 2$ of the mentioned Ordinance defines a crisis situation as an incident endangering life and health of people or their property caused by unlawful attacks that violate these goods, or a natural disaster, characterized by a possibility of control loss over the course of events or escalation of the threat, in which in order to protect security and public order it is necessary to use more police, including organized units and sub-units, also the armed ones ${ }^{35}$. Subsequently, the Ordinance defines a list of crisis situations. In the light of the regulations, they are: mass events at increased risk; public high-risk gatherings and celebrations; road blocks and occupations of buildings; organized pursuit operations; acts of terror; a collective breach of public security and order, in particular for social, economic, political and religious reasons; natural disasters, the effects of which may lead to social unrest; other situations that may pose a threat to life and health of people or property, as well as to public security and order characterized by a possibility of losing control over the course of events or escalating the threat, and requiring to use more police officers, including organized units and sub-units, also the armed ones in order to counteract or eliminate them.

It is worthwhile to note that the professional literature mentions several divisions of a crisis situation's categories, in which methods of conducted police negotiations may be applied. One is the division presented by K. Jałoszyński, according to which police negotiations can be conducted in connection with two types of crisis situations. The first of these are situations characterized by political crimes such as terrorist activity, more specifically taking hostages, blackmail, abducting people. A separate category of crisis situations which can be resolved using help of police negotiations are crisis situations that are incidents caused by people with emotional or personality disorders (the so-called "people in crisis"), for example suicide attempts or a threat caused by a security risk ${ }^{36}$.

32 Official Journal of the General Police Headquarters of Poland 2005 No 3, item 8.

${ }^{33}$ See more: Annex to Ordinance No. 1429 of the Police Commander-in-Chief of 31 December 2004, Journal of the General Police Headquarters of Poland 2005 Issue 3, item 8.

${ }^{34}$ Official Journal of the General Police Headquarters of Poland Issue 5, item 49.

35 See more: Ordinance No. 213 of the Police Commander-in-Chief of 28 February 2007 on the methods and forms of preparation and implementation of the police tasks in cases of threats to life and health of people or their property or public security and order.

${ }^{36}$ K. Jałoszyński, Niestandardowe negocjacje ..., p. 52-54; Communication activities in situations of threats to life and health are, however, taken not only by police officers, but also by other services in crisis situations. They are taken by representatives of medical specialties (psychiatry and psychology), health care staff, representatives of pedagogical specialties (especially resocialisation), prison staff, officers of the Internal Security Agency, security and rescue services (calming the rescued, preventing panic), municipal guards. Crisis negotiations are also conducted by persons dealing with counselling in solving life issues of shiftless persons, as well as people who do not work professionally conducting crisis negotiations and who participate, for example in family quarrels. Crisis negotiations therefore include all talks in crisis situations not only by the police and other uniformed services, but also by other people conducting talks in crisis situations. In a broad 
D. Piotrowicz defines a crisis situation as a coincidence of events, circumstances and behaviour that disrupt the proper functioning of the State, community and organization. The typical characteristics of a crisis situation include its usually sudden and unexpected occurrence and serious psychological, economic, legal and social consequences ${ }^{37}$. The division of crisis situations most commonly used in the professional literature indicates their two types. The first of these includes natural crisis situations, such as hurricanes, storms, earthquakes, floods, avalanches, volcano eruptions, fires, droughts, hailstorms, landslides, technical failures, poisonings, etc. The second group includes situations caused by man. The most frequent ones include: hostage taking, abductions, mass shootings, suicides, rapes, battery, riots, terror attacks, arson, road crashes ${ }^{38}$.

Due to the variety of definitions in the professional literature describing crisis situations, it should be emphasized that the purpose of this article is to present the subject of police negotiations conducted in order to solve crisis situations within the meaning of $\$ 2$ para. 2 of "Ordinance No. 4 of the Police Commander-in-Chief of 26 March 2002 on the forms and methods of police negotiations".

The situations in question may be caused by both one traumatic incident and long-term mini-crises such as negligence or conflicts in the educational, psychological, economic or organisational sphere ${ }^{39}$. However, stress plays a key role in the emergence of a crisis. The real threat of crisis occurs when stress grows to extraordinary proportions and ordinary ways of dealing with it become ineffective. As a result of failure to solve the problem and hence the inability to deal with it in a usual way, a spiral of ineffective behaviour called dysfunctional behaviour is activated. A crisis intervention means breaking this spiral in the fastest and most effective way possible, which means that the victim of the crisis is restored to the level of functioning from before the situation. It is worth emphasizing the significant role of a helping person, because the degree of his/her skills and the time needed to carry out the intervention can become a key element determining the victim's later development and the way of functioning ${ }^{40}$. In connection with the above, crisis negotiations will always focus on the subject being in the centre of a crisis. As a crisis-resolution technique, they provide a structured and effective way of influencing and facilitating the right behaviour of the person in a crisis ${ }^{41}$.

Analysing the undertaken negotiations in crisis situations in the context of police negotiators' work, attention should be focused on crisis situations that are a consequence of both

sense they are understood as transferring a classical definition of negotiations to a crisis, J. Stawnicka, Uwarunkowania prawno-organizacyjne prowadzenia negocjacji policyjnych [in:] Komunikacja w sytuacjach kryzysowych III..., p. 61-62. As Dariusz Biel emphasises, each conflict situation might develop into a crisis situation which would require negotiations or an intervention of third parties. Crisis negotiations are a specific form of crisis communication. The essence of their conduct is the process of reaching an agreement in a situation of interest differences, where a negotiation situation is accompanied by extreme emotions and behaviour which are of a destructive nature at the beginning, D. Piotrowicz, Negocjacje kryzysowe i policyjne. Wybrane zagadnienia psychologiczne oraz kryminologiczne, Warszawa 2010, p. 54.

${ }_{37}$ D. Piotrowicz, Negocjacje kryzysowe..., p. 57.

38 Ibid.

${ }^{39}$ D. Piotrowicz, Negocjacje kryzysowe..., p. 58.

40 J.L. Greenstone, S.C. Leviton, Interwencja kryzysowa, Gdańsk 2004, p. 15.

41 A. Slatkin, Crisis Negotiation for Law, Enforcement, Corrections and Emergency Services. Crisis Intervention as Crisis Negotiations, Springfield 2015, p. 15. 
said traumatic incidents ${ }^{42}$, understood as a serious threat to human life and health, as well as a consequence of difficult experiences such as conflicts or a loss of prized values. As a result of the difficulties, and if it is not possible to satisfy one's needs in a socially acceptable manner, a person in a crisis situation is extremely dangerous and unpredictable. The occurrence of these factors may result in a situation in which behaviour like suicidal manifestations or body injuries, or other criminal behaviour characterized by a high degree of aggression such as taking hostages or murder take place. It is worth emphasizing that in a so-called psychological crisis, the cause of which is depression and experienced family and material problems, the incidents often meet the criteria of mass murders, whose victims become members of the perpetrator's family, including children, and the perpetrator is usually a family member - father or mother, and often also a life partner of one of the victims ${ }^{43}$.

\section{ACTIVITIES OF THE NEGOTIATION SECTION OF THE OPERATIONAL SUPPORT DEPARTMENT OF THE ANTI-TERRORIST OPERATIONS BUREAU OF THE GENERAL POLICE HEADQUARTERS OF POLAND IN THE YEARS 2014-2016}

Due to the extent and complexity of the issue, the article attempts to present the role of police negotiators in solving crisis situations, as per Ordinance No. 4 of the Police Commander-in-Chief, according to which the following situations should be primarily considered as crisis situations: taking and detaining hostages; an announcement to commit a suicide; a perpetrator's threat to use a weapon or a dangerous tool or material against people and property. Analysing materials received from the General Police Headquarters of Poland (Komenda Gtówna Policji - KGP), the author of the article decided to present data on the work of negotiators of the Negotiation Section of the Operational Support Department of the Anti-Terrorist Operations Bureau of the General Police Headquarters of Poland in each of the three above-mentioned crisis situations in 2014-2016. When considering the work of police negotiators, it should not be forgotten that a list of crisis situations in which the police negotiation teams can participate is much longer. In addition, the activity of police negotiators fulfilling their functions in non-permanent provincial negotiation teams operating at Provincial Police Headquarters remains important in resolving crisis situations. In order to discuss comprehensively the subject matter presented in this study, the issue should be discussed from the perspective of all provinces, with a particular emphasis on such types of crisis situations that are characteristic for a given region of Poland. Due to some quantitative restrictions, this is impossible, but it can undoubtedly be a contribution to subsequent articles. In order to emphasize the significant role played by non-permanent police negotia-

42 J.L. Greenstone, S.C. Leviton, Interwencja..., p. 58; it is worth emphasizing that for almost four decades one has been able to observe a constantly growing interest in the effects of stress referred to as traumatic, which results in a significant increase in scientific works on the subject. One of the reasons is the introduction in 1980 by the American Psychiatric Association to the US classification of mental disorders of a new disease classification, termed post-traumatic stress disorder (PTSD). This event was a breakthrough in the history of research on extreme trauma, see more: M. Lis-Turlejska, Traumatyczne zdarzenia i ich skutki psychiczne, Warsaw 2005, p. 15.

${ }^{43}$ D. Piotrowicz, Negocjacje kryzysowe..., p. 58; It should be noted that police negotiators designated in Provincial Police Headquarters and the Warsaw Metropolitan Police Headquarters participate in total in solving of nearly 300 crisis situations per year, see more: D. Piotrowicz, negocjacje..., p. $50-51$. 
tors in the provinces, in this article I decided to present the activity of provincial police negotiators on the example of one provincial negotiation team. For this purpose, thanks to the courtesy of the officers from the Provincial Police Headquarters in Rzeszów, their data were used. Therefore, the article also presents data on the numbers of negotiators and their negotiations in the Podkarpackie Province in the years 2014-2018.

When analysing the material obtained from the KGP, the graphs were drawn. They present in turn, considering three crisis situations: the number of incidents reported in the indicated years related to taking and detaining hostages, announcements to commit a suicide, threats to use a weapon, a dangerous tool or material (Graph 1); the number and situations in which negotiations were conducted (Graph 2); and the number and types of incidents for which a negotiation team was designated, but negotiations were not started (Graph 3).

In the introduction to the analysis of the graphs provided below, it should be noted that each reported incident ended with police negotiations. Therefore, the situations to which a negotiation team was designated, and which ended in conducting negotiations should be distinguished from those incidents to which negotiators were designated, but for various reasons the negotiations were not carried out.

In the period from 1 January 2014 to 31 December 2016, the General Police Headquarters of Poland were reported the total of 62 incidents meeting the criteria of crisis situations within the meaning of $\S 2$ para. 3 of "Ordinance No. 4 of the Police Commander-in-Chief of 26 March 2002 on the forms and methods of police negotiations". The exact number of incidents, considering individual years is illustrated in Graph 1.

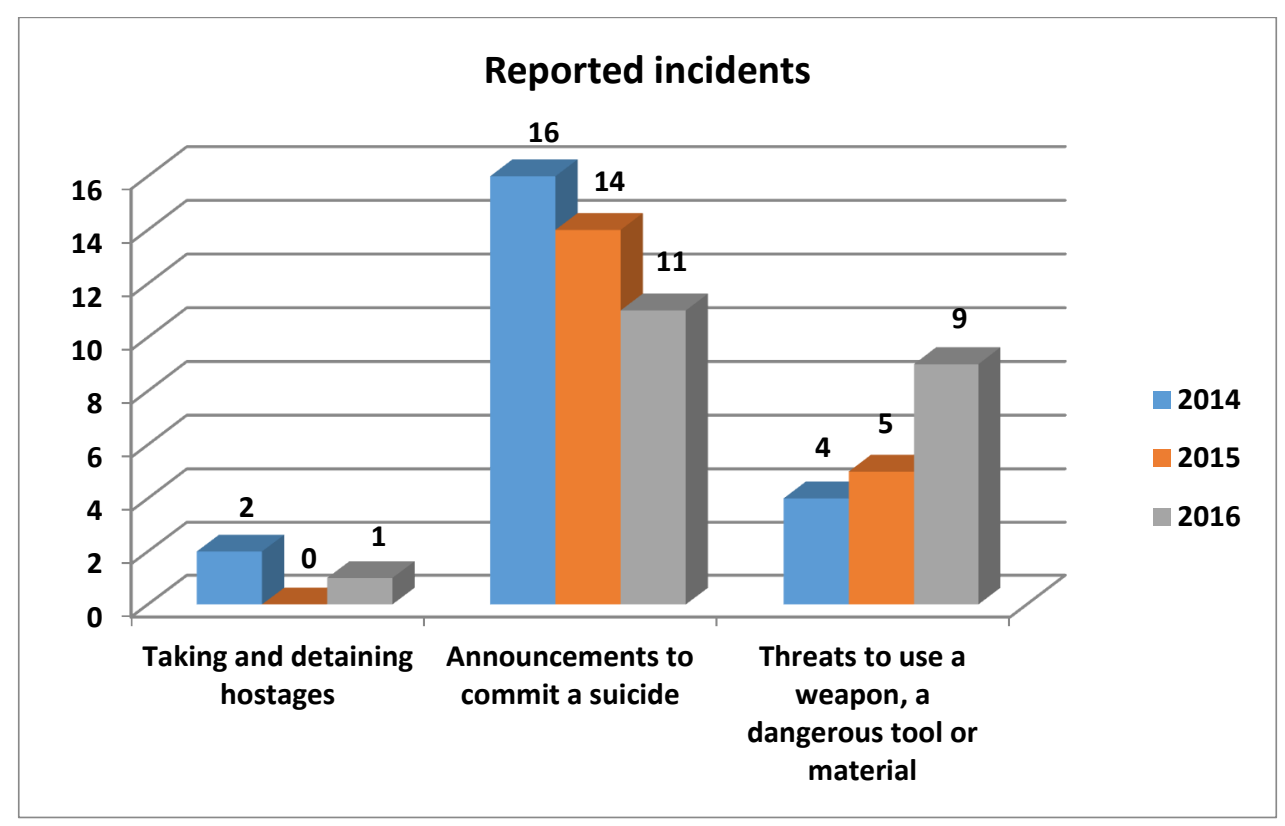

Graph 1. Incidents reported to the General Police Headquarters of Poland in the years 2014-2016 meeting the criteria of crisis situations within the meaning of $\S 2$ para. 3 of "Ordinance No. 4 of the Police Commander-in-Chief of 26 March 2002 on the forms and methods of police negotiations"

Source: Own study based on the data of the General Police Headquarters. 
The analysis of the statistical data of the General Police Headquarters of Poland has shown that during the studied period the largest group of reported incidents were those which concerned announcements to commit a suicide. Their respective number amounted to: in $2014-16$, in $2015-14$, in $2016-11$. The second largest group was a threat to use a weapon, a dangerous tool or material. In contrast to the previously discussed category related to the announcement to commit a suicide, in which a decreasing number can be observed, the number of reported incidents related to a threat to use a weapon, a dangerous tool or material more than doubled during the studied period: from 4 in 2014 to 9 in 2016. The smallest number of reported incidents concerned taking and detaining hostages. In the years 2014-2016 there were 3 incidents of this type in total.

The data presented above do not mean that police negotiations were conducted in each case. The list of the negotiation number carried out by the Negotiation Section of the AntiTerrorist Operations Bureau of the General Police Headquarters of Poland is presented in Graph 2.

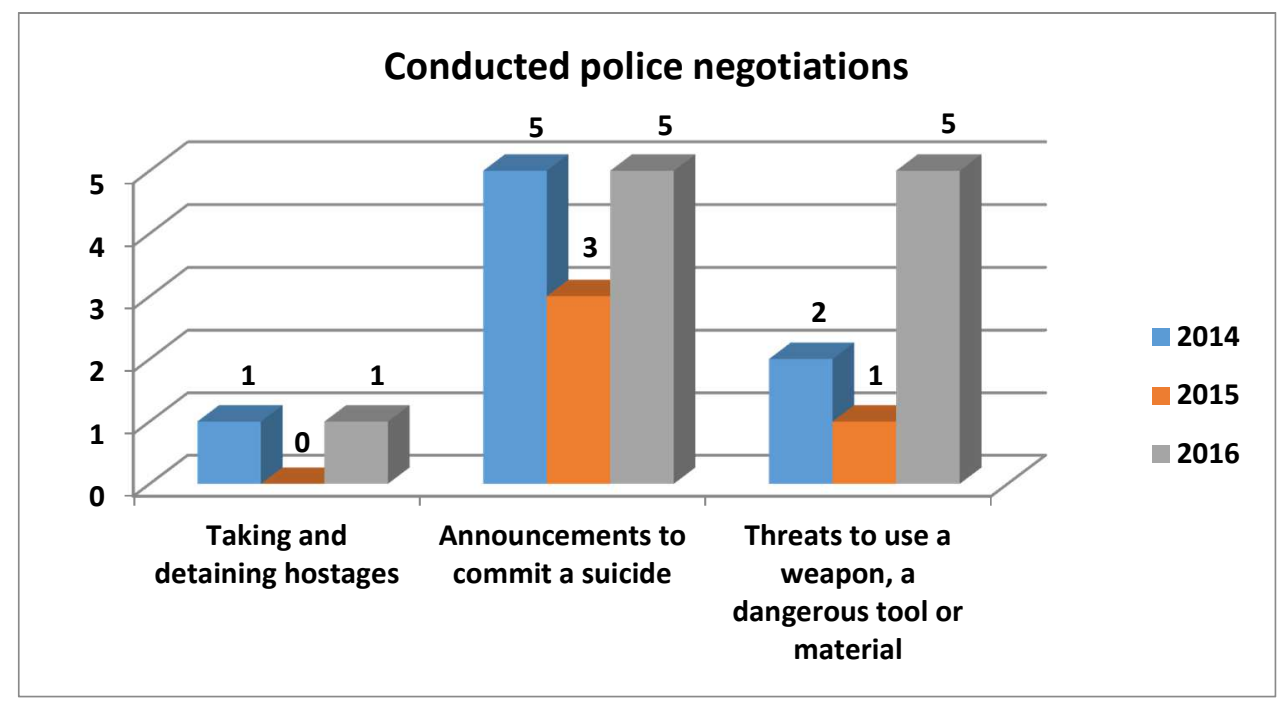

Graph 2. Police negotiations conducted by the Negotiation Section of the Anti-Terrorist Operations Bureau of the General Police Headquarters of Poland in the years 2014-2016

Source: Own study based on the data of the General Police Headquarters.

Based on the analysis of the police statistical data, it can be concluded that following the occurrence of three presented crisis situations, i.e.: taking and detaining a hostage; announcements to commit a suicide; a threat to use a weapon, a dangerous tool or material, the highest number of police negotiations were conducted in relation to the second of these listed categories. On the basis of the data obtained from the General Police Headquarters of Poland it can be noted that from 1 January 2014 to 31 December 2016 there were 13 police 
negotiations with persons announcing to commit a suicide. In the case of the latter category - a threat to use a weapon, a dangerous tool or material, there were 8 police negotiations in the analysed period. The lowest number, only 4 times did police negotiators intervene in incidents of taking and detaining hostages.

When analysing the data obtained from the General Police Headquarters of Poland, it is also possible to estimate the number of incidents for which a negotiation team was designated, but the negotiations were not started for various reasons. This is illustrated in the graph below.

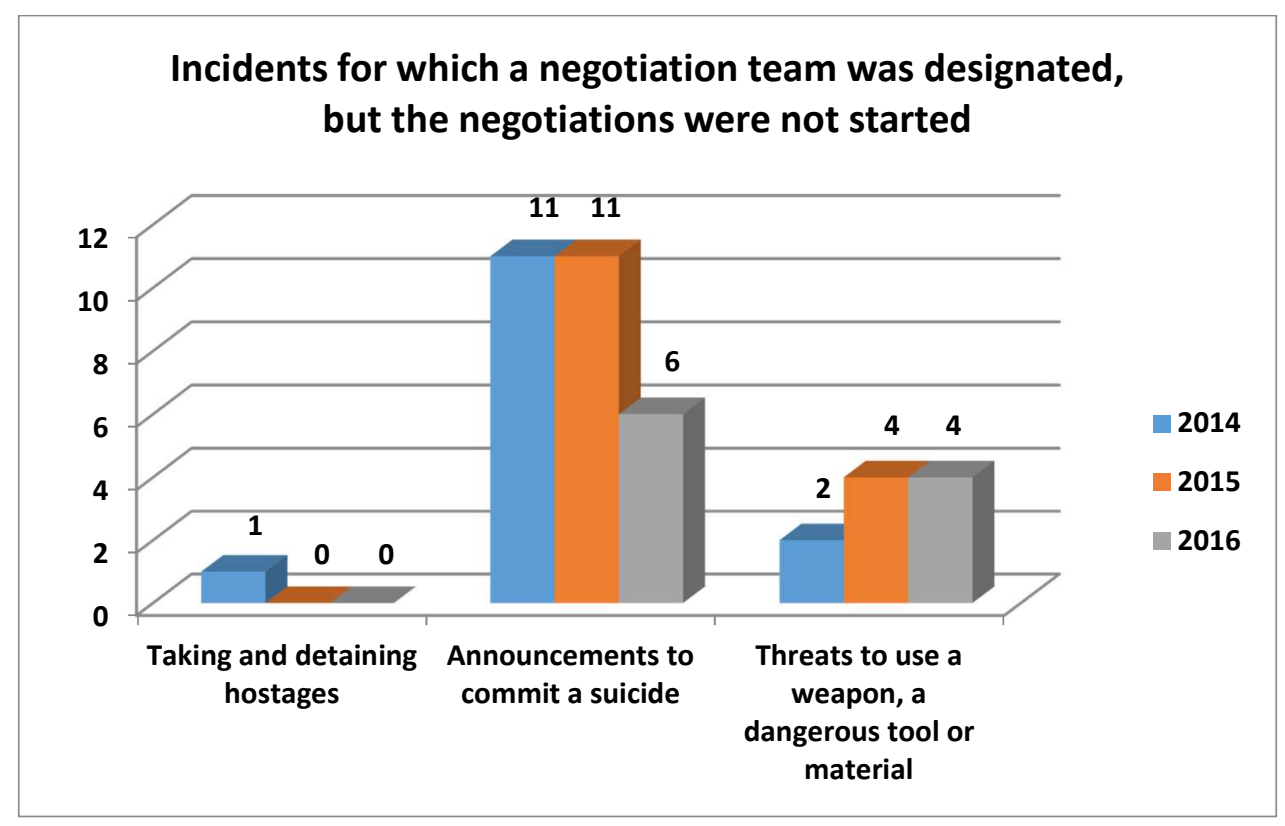

Graph 3. Incidents for which a negotiation team of the Anti-Terrorist Operations Bureau of the General Police Headquarters of Poland was designated, but the negotiations were not started

Source: Own study based on the data of the Police Headquarters.

Over the three analysed years, many situations can be observed in which, despite the fact that the commander of the police action or operation decided to designate a negotiation team, the negotiations did not take place. In connection with an announcement to commit a suicide, in the years 2014-2016 there were 28 such incidents for the total of 41 reported ones in this incident category. In the case of 18 reported incidents concerning a threat to use a weapon, a dangerous tool or material, there were 10 situations during which a negotiating team was designated but the negotiations were not started. In the case of three incidents of taking and detaining a hostage, there was one such situation. A team was designated but the negotiations were not started. 
In conclusion, it should be noted that the above statistics do not reflect the real scale of crisis situations. In fact, the need for interventions of police negotiators is much more frequent. To illustrate the situation, one can refer to the data, according to which in 2001 negotiators took part in 41 incidents, in 2015 in approximately 280. In the police there are approximately 300 negotiators - they are non-permanent negotiators. Therefore, the exact number of them is difficult to be determined; some resign, others are promoted. Full-time negotiators are in the Anti-Terrorist Operations Bureau of the General Police Headquarters. Among provincial police headquarters, only Łódź has a team of full-time negotiators. It was designated in 2006 by General Ferdynand Skiba, the Commander of the Garrison of Łódź of that time. And since that moment the Łódź negotiators have been called upon to crisis situations more and more often. However, it should be stressed that non-permanent negotiators function in each Provincial Police Headquarters and the Warsaw Metropolitan Police Headquarters. For example, in the Podkarpackie Province in March 2018 there were 22 police negotiators. The number of police negotiators of the Provincial Police Headquarters in Rzeszów over the years 2014-2018 is shown in the graph below.

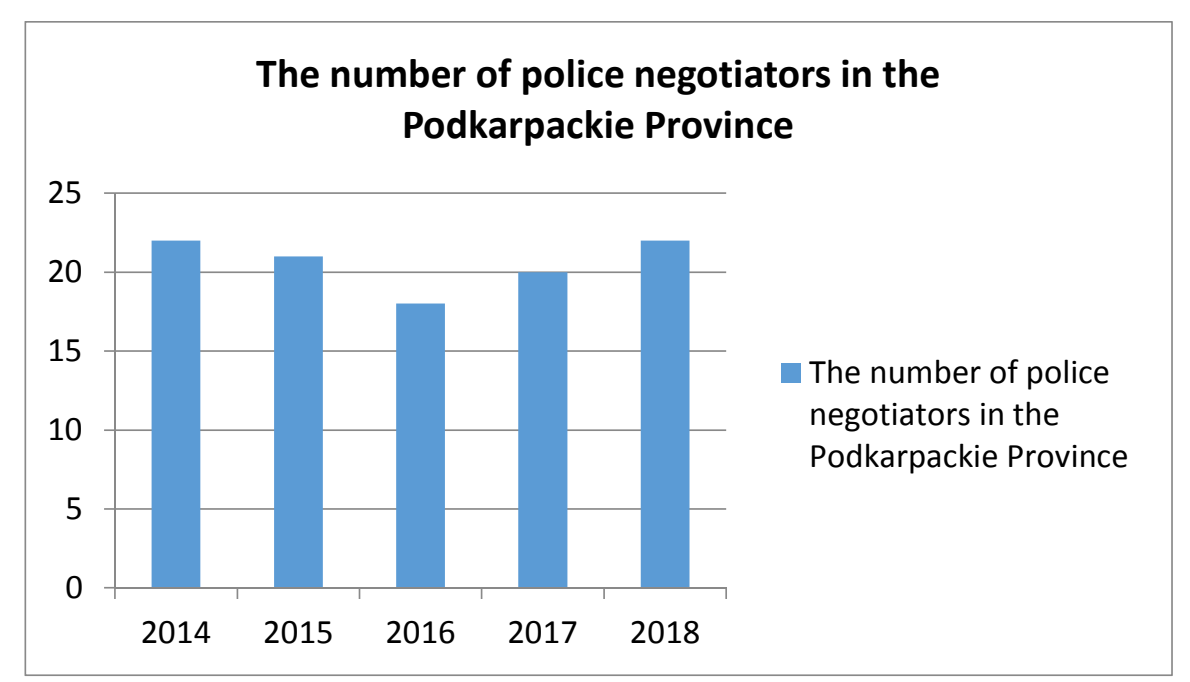

Graph 4. The number of police negotiators in the Podkarpackie Province (January 2014 - March 2018) Source: Own study based on the data of the Provincial Police Headquarters in Rzeszów.

On the basis of the data presented in the graph it can be noted that the number of police negotiators of the Provincial Police Headquarters in Rzeszów is relatively constant and varied over the years from 18 to 22, respectively in $2014-22$ negotiators in $2015-21$, in 2016 - 18, in 2017 - 20, in March 2018 - 22. This also corresponds with a relatively constant number of crisis situations to which negotiators were called in the area of the Podkarpackie Province. The types of crisis situations and the number of negotiations started in connection with them are presented in the table below. 
Table 1. Police negotiations conducted in the Podkarpackie Province (January 2014 - March 2018)

\begin{tabular}{|c|c|c|c|c|c|}
\hline $\begin{array}{c}\text { Conducted police negotiations related } \\
\text { to: }\end{array}$ & 2014 & 2015 & 2016 & 2017 & 2018 \\
\hline taking and detaining hostages & 0 & 0 & 1 & 1 & 0 \\
\hline an announcement to commit a suicide & 2 & 3 & 1 & 1 & 1 \\
\hline $\begin{array}{c}\text { a threat to use a weapon, a dangerous } \\
\text { tool or an explosive }\end{array}$ & 1 & 2 & 0 & 1 & 0 \\
\hline $\begin{array}{c}\text { another unlisted situation } \\
\text { In total per annum }\end{array}$ & 0 & 1 & 0 & 0 & 0 \\
\hline
\end{tabular}

Source: Own study based on the data of the Provincial Police Headquarters in Rzeszów.

By analysing the data obtained from the Provincial Police Headquarters in Rzeszów it can be concluded that from January 2014 to March 2018, the negotiators conducted negotiations in 15 crisis situations in total. As in the case of the Negotiation Section of the AntiTerrorist Operations Bureau of the General Police Headquarters of Poland, most of them concerned an announcement to commit a suicide. In the analysed period there were 8 incidents of this type. Fewer incidents involved the police negotiators intervening in the situations of threats to use a weapon, a dangerous tool or an explosive. There are 4 incidents of this type recorded in the police statistics. The fewest incidents, i.e. only two, were the negotiations conducted in incidents of taking and detaining hostages.

\section{SUMMARY}

Summing up the issue of police negotiations introduced in the article, it is necessary to emphasize the highly justified need to establish negotiation teams both on the provincial scale and at the central level of the Police authorities. It corresponds in a strict way with the increasing occurrence and significant escalation of crisis situations, as a result of which there is a breach of public security and order. There is no doubt that these situations are in the vast majority of them identified with the criminal character of the actions of the perpetrators of these incidents. Therefore, the more important are the police's actions related not only to combating this type of incidents, but above all to preventing the emergence of a crisis situation which results in a threat to life or health. It corresponds in a strict way with the tactical and criminal aspects of the police negotiators' work, and thus with their implementation of basic criminalistic functions by detecting, recognizing, commanding and preventing criminal activities.

In conclusion, it must be stated that police negotiations as tactics of peaceful resolution of crisis situations without the use of force are becoming increasingly important in present times. Police negotiators are high-class properly trained professionals whose superior skills predispose them to resolve crisis situations characterised by a high level of stress and danger. 


\section{REFERENCES}

1. Biel D., Badania sytuacji kryzysowych/policyjnych. Wstęp do dyskusji [in:] Komunikacja w sytuacjach kryzysowych III, ed. J. Stawnicka, D. White, Katowice 2011.

2. Bowen E., Brown S.J., Grubb A.R., Hall P., From "Sad People on Bridges" To "Kidnap and Extortion": Understanding the Nature and Situational Characteristics of Hostage and Crisis Negotiator Deployments, "Negotiation and Conflict Management Research" May 2018.

3. Greenstone J.L., Leviton S.C., Interwencja kryzysowa, Gdańsk 2004.

4. Greenstone J.L., The Elements of Police Hostage and Crisis Negotiations: Critical Incidents and How to Respond to Them, London and New York 2008.

5. Grubb A.R., An Exploratory Mixed-Methodological Analysis of Police Hostage and Crisis Negotiation in the United Kingdom, Coventry 2016.

6. Grubb A., Brown S., Hall P., Personality traits and coping styles in UK police officers. Do negotiators differ from their non-negotiator colleagues?, "Psychology, Crime and Law", Vol. 21(4) 2015.

7. Hanausek T, Kryminalistyka, Kraków 2005.

8. Jałoszyński K., Niestandardowe negocjacje policyjne [in:] Komunikacja w sytuacjach kryzysowych III, ed. J. Stawnicka, Katowice 2012.

9. Kelln B., McMurtry C.M., STEPS-Structured Tactical Engagement Process A Model for Crisis Negotiation, "Journal of Police Crisis Negotiations", Vol. 7 2007, $29-51$.

10. Lis-Turlejska M., Traumatyczne zdarzenia i ich skutki psychiczne, Warszawa 2005.

11. Loranty D., Zasady prowadzenia negocjacji ze sprawcami zamachów terrorystycznych [in:] Wspótczesne zagrożenia terroryzmem oraz metody dziatań antyterrorystycznych, ed. J. Szafrański, Szczytno 2007.

12. Macmains M.J., Mullins W.C., Crisis Negotiations. Managing Critical Incidents and Hostage Situations in Law Enforcement and Corrections, London and New York 2015.

13. Pearce K., Police negotiations. A new role for the community psychiatrist, "Canadian Psychiatric Association Journal", 1977 Jun;22(4).

14. Piotrowicz D., Negocjacje kryzysowe i policyjne. Wybrane zagadnienia psychologiczne oraz kryminologiczne, Warszawa 2010.

15. Piotrowicz D., Negocjacje kryzysowe w policyjnym systemie interwencyjnym. Bezpieczeństwo Mistrzostw Europy w pitce nożnej Euro 2012, ed. K. Liedel, P. Piasecka, Warszawa 2011.

16. Po pierwsze człowiek, „Policja 997”, Issue 148/07.2017

17. Rubio A., Perceived outcomes of Swat Negotiations with a Police Psychologist on the Crisis Negotiations Team, Dissertation Submitted to the Faculty of the California School of Forensic Studies, Los Angeles 2015.

18. Slatkin A., Crisis Negotiation for Law, Enforcement, Corrections and Emergency Services. Crisis Intervention as Crisis Negotiations, Springfield 2015.

19. Stawnicka J., Uwarunkowania prawno-organizacyjne prowadzenia negocjacji policyjnych [in:] Komunikacja w sytuacjach kryzysowych III, ed. J. Stawnicka, Katowice 2012.

20. Stępiński M., Działalność Biura Operacji Antyterrorystycznych Komendy Gtównej Policji w 2013 r., „Kwartalnik Policyjny”, Issue 1/2014.

21. Stępiński M., Negocjacje policyjne. Narzędzie alternatywnego rozwiazania sytuacji kryzysowej, „Kwartalnik Policyjny”, Issue 1/2014. 
22. Wieczorek A., Negocjator w cieniu akcji, www.police.pl.

23. Żółtowski J., Funkcjonowanie systemu negocjacji policyjnych w Polsce [in:] Stużby i formacje mundurowe w systemie bezpieczeństwa wewnętrznego Rzeczypospolitej Polskiej, ed. E. Ura, S. Pieprzny, Rzeszów 2010.

\section{INTERNET SOURCES}

1. Staff P., Police Negotiation Techniques from the NYPD Crisis Negotiations Team, 20.02.2018, www.pon.harvard.edu.

\section{TAKTYCZNE I KRYMINALISTYCZNE ASPEKTY NEGOCJACJI POLICYJNYCH W SYTUACJACH KRYZYSOWYCH}

Zespoły negocjatorów policyjnych, wzywanych w sytuacji kryzysowej, są bardzo ważne w taktyce policyjnej. Ich zadaniem jest nawiązanie komunikacji werbalnej ze sprawcą sytuacji kryzysowej i doprowadzenie do pokojowego rozwiązania problemu. Można zatem założyć, że celem negocjacji jest sprawienie, aby sprawcy lub sprawca poddali się, a także w sytuacji, gdy istnieje realna groźba dla życia osób biorących udział w sytuacji kryzysowej, aby można było „kupić czas” na przygotowanie najlepszych możliwości innego rozwiązania taktycznego (np. atak). Negocjacje policyjne są traktowane jako alternatywa dla rozwiązań wykonawczych w sytuacjach kryzysowych, np. użycie snajperów. Pierwsza sekcja negocjtorów w Polsce powstała w 1992 roku. Dwa lata później założono, że w każdym województwie zostaną utworzone sekcje negocjatorów policyjnych. Obecnie pełnoetatowi negocjatorzy pełnią służbę w Sekcji Negocjacji Departamentu Wsparcia Operacyjnego Biura Operacji Antyterrorystycznych Komendy Głównej Policji, a nieformalne zespoły negocjacyjne działają w każdej komendzie wojewódzkiej oraz w Komendzie Stołecznej Policji.

Słowa kluczowe: negocjacje policyjne, sytuacja kryzysowa, taktyka, samobójstwo, zakładnik, niebezpieczne narzędzie, materiały wybuchowe.

DOI: $10.7862 /$ rz.2018.hss.86

Przestano do redakcji: lipiec $2018 \mathrm{r}$. Przyjęto do druku: grudzień 2018 r. 
